Covered in: Web of Sciences (WOS); EBSCO; ERIH+; Google Scholar; Index Copernicus; Ideas RePeC; Econpapers; Socionet; CEEOL; Ulrich ProQuest; Cabell, Journalseek; Scipio; Philpapers; SHERPA/RoMEO repositories; KVK; WorldCat; CrossRef; CrossCheck

2018, Volume 10, Issue 4, pages: 82-91 | doi: https://doi.org/10.18662/rrem/74

\section{Study on Sports Activities in the Free Time of Gymnasium Cycle Students}

\section{Alina Ionela CUCUI ${ }^{1}$}

${ }^{1}$ Associate professor, $\mathrm{PhD}$, Valahia University from Targoviste, Romania, haralambiealina2008@yahoo.com
Abstract: The planned daily routine, either at home or in the education system, for secondary school students, can be an inhibiting factor for full personality manifestation if it is not taken up by a spare time left out for everyone to consume. The more important this aspect is for puberty children who form life skills, they form their personality and who, in order to support it in evolution, need a dowry of free time greater than adults.

Consequently, the objectives of our study are devoted to researching how leisure time is consumed by gymnasts and the partition they are assigned to physical activities.

The paper aimed to conduct a survey based on a questionnaire, in which the subjects expressed their opinions on the proposed topic.

The results revealed that pupils in grades 5 and 6 are still interested in sports activities. As we moved to the upper classes of the gymnasium cycle, we noticed the increased interest of students in technology.

The findings of this research highlight the directions towards which the young generation is heading. Clearly, her concerns have diversified much with the huge leap that the IT revolution has made. Students are increasingly moving away from a healthy lifestyle with the possibility of harmonious development both physically and mentally.

Keywords: leisure; sports activities; students;

How to cite: Cucui, A.I. (2018). Study on Sports Activities in the Free Time of Gymnasium Cycle Students. Revista Romaneasca pentru Educatie Multidimensionala, 10(4), 82-91. https://doi.org/10.18662/rrem/74 


\section{Introduction}

Today, any form of sport activity is pursued and known almost all over the world, but less and less interesting for younger generations. Today's technique is so advanced that young people are captivated and hard to break out of this world if they have got to know it.

Even if it does not, it's a reality. Free time, engaging in motoring activities, be they sports, is being rejected by more and more children aged 11-14 and supplemented with computer activities or other information technologies.

Free time encompasses the period when the human being is not subject to duties, tasks to be fulfilled, is "something outside of human obligations, a kind of space of complete individual liberty" (Albert, 1970).

According to the literature, three main functions can be attributed to leisure time (Aluass \& Dragan, 1971): rest - which frees from fatigue, entertainment - which frees from boredom and the development of personality - which frees from the automatisms of everyday thinking and action, mainly used in work.

Rest refers to an opportunity with the aim of restoring indispensable powers, physical and mental abilities (Albert, 1970). Rest in the narrow sense has the power to improve the physical state of an individual, to eliminate the feeling of labor, the toil gained from professional tasks or other activities undertaken in the daily reality (Oprescu, 1981).

For the preservation of a physiological system in the parameters of normality, it is necessary in the context of free time, individuals to pay more attention to the relationship of rest - health. Francis Albert highlights as a function of free time and the function of beauty and recreation, namely entertainment. The aesthetic-leisure function of leisure time is meant to remove boredom either through cultural-artistic life - cinemas, theater performances, opera, reading, concerts, or recreation - trips, excursions, hiking in the open air. In the aesthetic and recreational function, a highly formative value activity is reading (Albert, 1970).

Defining in the harmonious development of the personality of young people is the movement, the driving activities. Commercial routes applicative used in the physical education teaching contents and guidelines have and can take multiple forms of organizing and running very varied (Cucui, 2017b). It is from this premise that the research of Kirițescu (1964) goes. His study analyzes the history of physical exercise since the appearance of man (the lower Paleolithic), passing through the Mesolithic and reaching 
the Neolithic of the slave society. Summary, Kirițescu link exercise primary physiological needs of man (homo primigenius), but also his pride to rise "above the stage animal" (Kirițescu, 1964).

The beginnings of physical exercise, according to the same author, have their origins in "the four fundamental movements: running, jumping, climbing, fighting" (Kiriţescu, 1964). With the passage of time, man has subjected himself to the needs and whims of the nature of his will, the life of the individual has changed considerably. He does not spend all his time looking for food, leaving him time for rest, recreation, celebration, enjoyment or the reality of our present technology.

Interesting moves have also suffered from time spent with daily programs. Work days have considerably diminished their time. It is no longer necessary for the whole day to be a sacrifice sacrificed on the altar of survival. There is plenty of time remaining for the other needs of Maslow's top of the pyramid, such as reading, relaxing, practicing some sports exercises, virtual sailing, hiking, thematic or adventure trips. Of course, all of them, in their own way, can be practiced by anyone, diachronically, throughout their lives, according to their habitual habits.

However, we must not forget why the human body is a complex machine, as the philosopher Leibniz, who needs diversity to maintain himself in shape and preserve his health. Lately in sport substantial changes were due to the dynamics of development of sports (Cucui \& Cucui, 2014).

Sports activities as a whole are conditioned by the personality of the individual because they have psychosocial dimensions. It is imperative that teaching will be conducted in a manner to develop and sustain students' interest in the activity carried out, to guide them in learning activities and independent practice physical exercise (Cucui, 2017a).

Therefore, today, "studies of the knowledge of personality gain a growing weight in the contemporary psychology of sport" (Epuran \& Holdevici, 1980).

Recent approaches the educational process from the perspective of the system have highlighted the need to establish the link between action and evaluation, namely coherence between goals, action and results (Cucui, 2017a).

We live in society, we do not live as individuals isolated from each other, so our lives are conditioned by others, our activity causes others to suffer. Sport is an activity that mobilizes masses that create passions that motivate people that require engagement and participation, and that is why the cult for sports activities must be inoculated to young people even in leisure time. Motivation is one of the important factors of sporting performance. It can be named sporting performance source (Haralambie \& Mihăilescu, 2010). 
Its necessarily need a systemic approach leads to emphasis on the dynamics of the activities (Cucui, 2015). It's a benefit for everyone. Not in vain did they deal with the past, so many of them have been taught to make "the importance and the social value ... and its balanced influence on the mental health of men" (Epuran, \& Holdevici, 1980), remarked M. Epuran.

Establishing appropriate content, rich in valences of educational, ensuring proper organization, able to contribute to the promotion of relations and behavior-targeted, consistent training objectives pursued, constitute basic conditions for the process to serve the education and training (Cucui, 2017b) of individs.

Free time includes activities such as: voluntary work and meetings; social life and entertainment including cultural activities; sports activities, hobbies and computer use; media (reading, watching TV, radio) (INS, 2013).

Thus, we can conclude that "the structure of leisure time is influenced by socio-demographic characteristics (gender, age, civil status), level of education, degree of culture, occupation, level of income, living and transport conditions, cultural conditions (traditions), subjective factors (the individual's skills, desires, aspirations, the perception he gives to each leisure time, the degree of commitment to social and political life)" (Angelescu \& Jula, 1997).

Democritus, a great Greek thinker, was telling the world that he is in a permanent process of transformation and becoming. Nothing remains the same. "You can not scrub twice in the waters of the same river," he said of the permanent change of the world. Change does not necessarily mean moving from worse to better. Sometimes the process may be reversible in certain activities or areas. This is the hypothesis from which our research goes. The need to know reality in the context of current advanced technology has led me to investigate students' vision of sports activities. The specialized literature abounds in the presentation of the benefits of movement in general, but less we see attractive sports programs, opportunities for accessing the tower by the middle school students. In this context, we thought it would be appropriate to know the pupils' opinion, to see if the gymnasium students are attracted to sports activities.

\section{Hypotheses}

Subjects aged 11-15 are the age category that has the largest free time budget that can be dedicated to sports activities.

Starting from this, I considered it particularly important to see if technology, current trends in modern technology reduced the time for 
practicing sports, and that would be the current partition of sports activities in the free time budget.

\section{Materials and Methods}

Starting from the purpose of our research, namely to find out whether there is also a concern for sports activities in the free time of gymnasium students, I have resorted to a questionnaire on the specificity of this research (Table 1). Therefore, the main method by which we collected the necessary data is the questionnaire survey. It is the most used method in research, being the most well-known, is sometimes identified with sociological research itself (Cucui, 2018). The method of investigation, by developing and expanding investigations in various fields and, especially in social sciences, has gained a great prestige (Cucui, 2018). It should be noted that the questions have been formulated and grouped in such a way as to cover the tasks that research has proposed: see how many hours during the working week (Monday to Friday) are allocated to sports activities. It was also my concern to find out how and how is free time used by age groups (grades V-VI and VII-VIII) and sexes, if there are differences in the use of leisure time between urban and rural areas.

Table 1 Questionnaire on partition free time during the week

\begin{tabular}{l}
\hline No. Item of the questionnaire \\
\hline 1. How much free time do you have on a working day (Monday on \\
Friday)? \\
2. From your free time, how much time do you do for sports (football, \\
tennis, gymnastics, fitness, handball, etc.)? \\
3. How much free time do you use on facebook, tablet, phone and \\
other IT technologies during the week? \\
4. How much of your free time do you spend with cultural activities \\
(topics, writing, reading) helping parents? \\
5. How much free time on weekdays do you use to walk around town, \\
excursions, malls, cafes, etc?
\end{tabular}

In order to process the data collected through the questionnaire, we set out the scores for the response variants as follows: for all the variants of the answer, a (1) point is given, for the variant $b$ two (2) points are given, for the answer variant $\mathrm{c}$ is given three (3) points and for the variant $\mathrm{d}$ four (4) points are awarded. The points are multiplied by the number of options and thus the score points are set, scores that are decisive for showing the trends of secondary school students for leisure. 
60 subjects were involved in the research, 40 in the urban area, 20 in the rural area. Out of the 40 students surveyed in the urban area 20 were from the 5th and 6th grades, and other 20 from the 7th-8th grades. 20 pupils from the 7 th to 8 th grades were surveyed in rural areas.

Sample formation was based on a random selection of middle school students between the ages of 11 and 15 . The interviewed subjects are part of the Tudor Vladimirescu High School in Târgovişte, and the rural ones are from the Ocniţa Gymnasium School. Following discussions with physical education teachers that allowed us access to classes in these school units, I applied to apply the questionnaire to students who have expressed their willingness to take part in this research.

\section{Results}

After analyzing and interpreting the questionnaires, there are several directions to which the young generation is oriented. Clearly, her concerns have diversified much with the huge leap that the IT revolution has made. Consequently, it directly influences the lives of young people today. It is not by chance that the answers of the students in the lower cycle of the gymnasium differ from those of the upper level in leisure activities on various activities.

From the processing of the results, it emerged that at the fifth and sixth grade pupils give the most of their free weekly sports activities. While in the 7th and 8th grades, students devote much of this time to virtual activities, achieving a score of 114 points, followed by cultural activities, leisure activities and, last, sports activities with 86 points. 


\section{Chart no. 1 Partition of middle school students' preferences in a week}

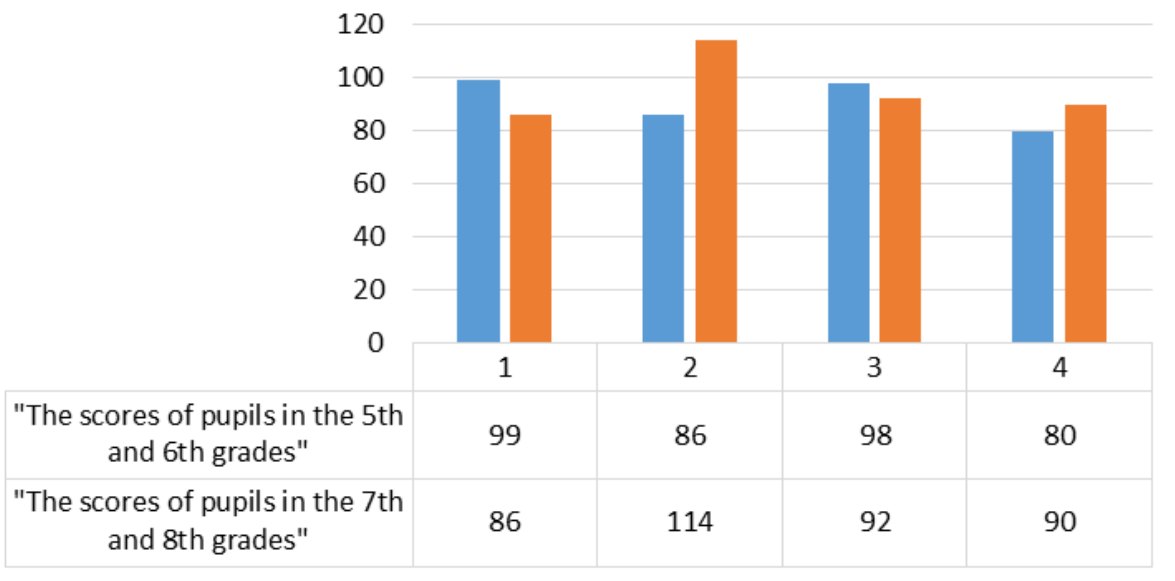

Another approach to this research highlights gender differences in terms of leisure activities. Mostly female females' preoccupations in their free time pivoted to three non-active axes, the use of information technology (114pct.), And readout activities (104) and family time (86). Boys have clear options on exercise and sporting practices, as demonstrated by their options (105).

\section{Chart no. 2 Free Time Partition by Gender to middle school students}

\begin{tabular}{|c|c|c|c|c|}
\hline \\
\hline \multicolumn{5}{|l|}{100} \\
\hline 80 & & & & \\
\hline 60 & & & & \\
\hline 40 & & & & \\
\hline 20 & & & & \\
\hline 0 & 1 & 2 & 3 & 4 \\
\hline Male student results & 105 & 86 & 86 & 84 \\
\hline $\begin{array}{l}\text { The results of female } \\
\text { students }\end{array}$ & 80 & 114 & 104 & 86 \\
\hline
\end{tabular}


From the comparative analysis of leisure preferences with various activities between urban and rural areas, the option difference is evident. Those in rural areas are in a relative balance of leisure activities, except for cultural activities with a score of 112 points. Sport almost equally appreciated and practiced as activities dedicated to the family. While the pupil of the city is much closer to the virtual activities than the cultural ones, the ones dedicated to the family and more distant from the sports activities, which are ranked last in the preferences of the upper secondary school students.

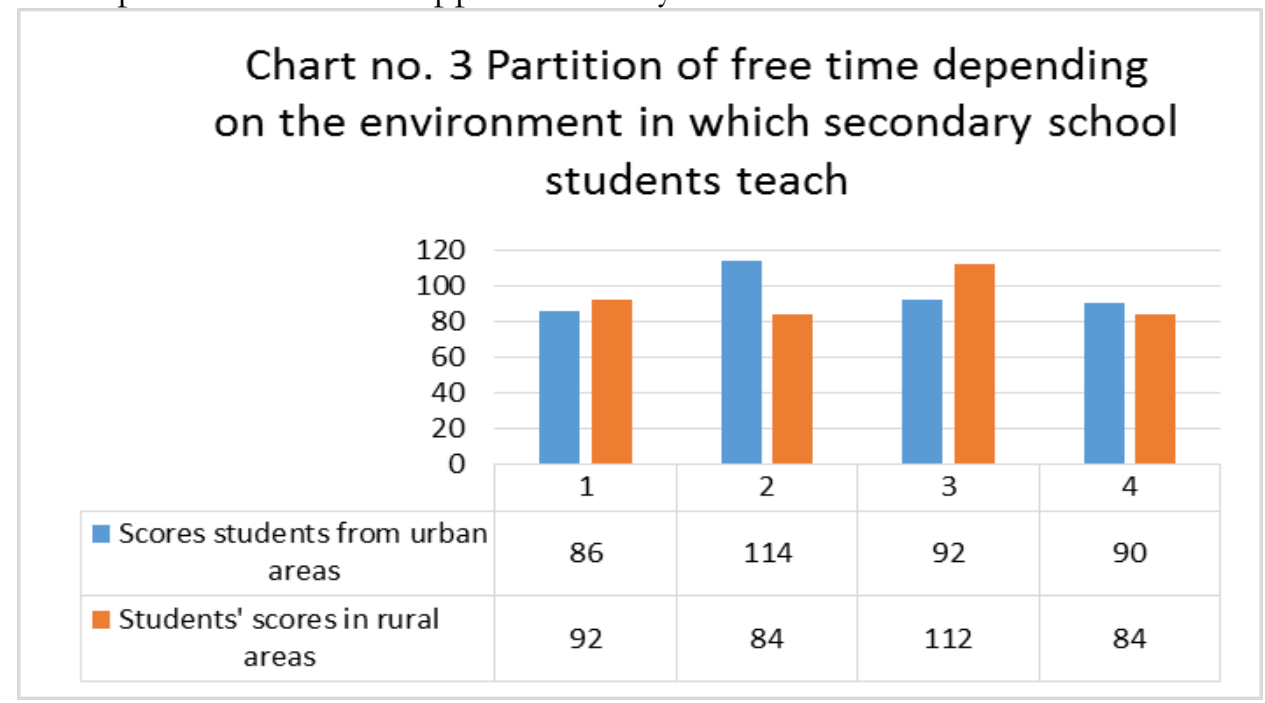

\section{Conclusions}

1. The preoccupations of middle school students have been greatly diversified with the huge leap of the information technology revolution that directly influences the lives of young people today.

2. From the comparative analysis of the leisure preferences with various activities between urban and rural areas, the difference of choice is obvious. Students in rural areas are in a relative balance of leisure activities. Sport is equally appreciated and practiced as activities dedicated to the family. While the pupil in the city is much closer to sports than to cultural and family activities.

3. Gender differences in leisure activities are also obvious. Mostly women's leisure concerns focus on the use of information technology and leisure activities through reading and family time.

4. Male subjects have clear options for exercise and sports practices, as demonstrated by their options, with a score of 105 vs. 86, the female sex score. 


\section{Discussions}

About sport activity we all know that it helps us get rid of extra pounds and shapes us nicely the silhouette. But the beneficial effects of regular exercises do not stop there. The movement can help us be more confident, less stressed and more disciplined, extremely important considerations during the student's development.

Promoting systematic physical activity, regardless of age, has been designated in the United States as a national health priority. In this context, many people, physicians and healthcare professionals, physical education and sports teachers as well as government policies could influence the evolution of the health of the population by promoting systematic physical activity. For every five minutes of exercise, we add one extra minute to our lives. Sports activities irrespective of the programs they are practicing are particularly important because they provide us with a good state of affairs and ensure the maintenance of physical and mental health. By practicing exercise, the body's devices and systems will increase their functional performance and improve their activity, consolidating their structure.

Knowing the benefit of physical exercise, it is imperative to create new opportunities to attract and involve gymnasium students in performing sports activities.

Both in urban and rural areas, it is necessary to intervene to help children develop harmoniously, learn to adopt a healthy and balanced lifestyle. which should be treated with the utmost seriousness by all actors involved in the education process of pupils in order to achieve the goals of modern education as well as attaining the objectives of physical education and sport.

Research is in the focus area of speculators, which is confirmed by the above-mentioned interests in the benefits gained from sporting activities. This is part of a broader research into the priorities of students in their free time.

\section{References}

Albert, F. (1970). Dialog cu timpul liber [Dialogue with leisure time]. Bucharest, Romania: Politică.

Aluaş, I., \& Drăgan, I. (1971). Sociologia franceză contemportană - teorie, metodologie, tehnici, ramuri [Contemporary French sociology - theory, methodology, techniques, branches]. Bucharest, Romania: Politică.

Angelescu, C., \& Jula, D. (1970). Timpul liber. Condiţionări şi implicații economice [Free time. Conditions and implications economic]. Bucharest, Romania: Economică. 
Cucui, G. G. (2015). Systemic vision - its necessity in the management of sports organizations. The European Proceedings of Social \& Behavioural Sciences (pp. 326-333), MEPDEV 2nd: 2016 Central \& Eastern European LUMEN International Conference - Multidimensional Education \& Professional Development. Ethical Values. doi:10.15405/epsbs.2016.06.45

Cucui, G. G., \& Cucui, I. A. (2014). Research on the management of sports organizations. In Maree, K. (Ed.), Procedia - Social and Behavioral Sciences (pp. 667-670) (vol. 140), 2nd World Conference on Psychology and Sociology, PSYSOC 2013, 27-29 November 2013, Brussels, Belgium. Amsterdam, Netherlands: Elsevier. doi:10.1016/j.sbspro.2014.04.490.

Cucui, G. G. (2017a). Evaluation in physical education and sport. The European Proceedings of Social \& Behavioural Sciences (pp. 100-105), MEPDEV 2nd: 2016 Central \& Eastern European LUMEN International Conference Multidimensional Education \& Professional Development. Ethical Values. doi:10.15405/epsbs.2017.07.03.14

Cucui, G. G. (2017b). Tracks utilitarian of applicative - means psychomotor skills development to young schoolchildren. The European Proceedings of Social \& Behavioural Sciences (pp. 106-110), MEPDEV 2nd: 2016 Central \& Eastern European LUMEN International Conference - Multidimensional Education \& Professional Development. Ethical Values. doi:10.15405/epsbs.2017.07.03.15

Cucui, G. G. (2018). Metode de cercetare în educatie fizică și sport [Research methods in physical education and sports]. Piteşti, Romania: Editura Universității din Pitești.

Epuran, M., \& Holdevici, I. (1980). Compendiu de psibologie pentru antrenori [Compendium of psychology for coaches]. Bucharest, Romania: SportTurism.

Haralambie, A., \& Mihăilescu, L. (2010). Research concerning the motivation's quantification for performance athletes. Citius Altius Fortius, Journal of Physical Education and Sport, 27(2), 79-85.

Institutul Național de Statistică (INS). (2013). Utilizarea timpului în România [Use of time in Romania]. Press release no. 307, 2013, December 20. Retrieved from http://www.insse.ro/cms/ro/content/utilizarea-timpului-romania

Kirițescu, C. (1964). Palestrica. Bucharest, Romania: Editura Uniunii de Cultură Fizică şi Sport.

Oprescu, D. (1981). Timpul liber şi înstrăinarea umană [Free time and human estrangement]. Bucharest, Romania: Politică. 